\title{
Correcting field determination of elemental contents in soils via portable X-ray fluorescence spectrometry
}

\section{Correção da determinação em campo dos teores de elementos em solos via espectrometria de fluorescência de raios- $X$ portátil}

\author{
Thaís Santos Branco Dijair ${ }^{1}(\mathbb{D})$, Fernanda Magno Silva ${ }^{2}{ }^{(D)}$, Anita Fernanda dos Santos Teixeira ${ }^{2}$ (D), \\ Sérgio Henrique Godinho Silva ${ }^{2}$ (D), Luiz Roberto Guimarães Guilherme ${ }^{2}$ (D), Nilton Curi ${ }^{2 *}$ (iD)
}

${ }^{1}$ Universidade Federal de Lavras/UFLA, Lavras, MG, Brasil

¿Universidade Federal de Lavras/UFLA, Departamento de Ciências do Solo/DCS, Lavras, MG, Brasil

*Corresponding author: niltcuri@ufla.br

Received in January 31, 2020 and approved in May 8, 2020

\begin{abstract}
Portable X-ray fluorescence (PXRF) spectrometry has been useful worldwide for determining soil elemental content under both field and laboratory conditions. However, the field results are influenced by several factors, including soil moisture (M), soil texture (T) and soil organic matter (SOM). Thus, the objective of this work was to create linear mathematical models for conversion of $\mathrm{Al}_{2} \mathrm{O}_{3^{\prime}} \mathrm{CaO}_{1} \mathrm{Fe}, \mathrm{K}_{2} \mathrm{O}$, $\mathrm{SiO}_{2}, \mathrm{~V}, \mathrm{Ti}$ and $\mathrm{Zr}$ contents obtained by pXRF directly in field to those obtained under laboratory conditions, i.e., in air-dried fine earth (ADFE), using $\mathrm{M}, \mathrm{T}$ and SOM as auxiliary variables, since they influence pXRF results. pXRF analyses in field were performed on 12 soil profiles with different parent materials. From them, 59 samples were collected and also analyzed in the laboratory in ADFE. PXRF field data were used alone or combined to $\mathrm{M}, \mathrm{T}$ and SOM data as auxiliary variables to create linear regression models to predict pXRF ADFE results. The models accuracy was assessed by the leave-one-out cross-validation method. Except for light-weight elements, field results underestimated the total elemental contents compared with ADFE. Prediction models including $T$ presented higher accuracy to predict $\mathrm{Al}_{2} \mathrm{O}_{3}, \mathrm{SiO}_{2}, \mathrm{~V}$, $\mathrm{Ti}$ and $\mathrm{Zr}$, while the prediction of $\mathrm{Fe}$ and $\mathrm{K}_{2} \mathrm{O}$ contents was insensitive to the addition of the auxiliary variables. The relative improvement $(\mathrm{RI})$ in the prediction models were greater in predictions of $\mathrm{SiO}_{2}(\mathrm{~T}+\mathrm{SOM}: \mathrm{Rl}=22.29 \%), \mathrm{V}(\mathrm{M}+\mathrm{T}$ : $\mathrm{Rl}=18.90 \%)$ and $\mathrm{Ti}(\mathrm{T}+\mathrm{SOM}$ : $\mathrm{Rl}=11.18 \%)$. This study demonstrates it is possible to correct field pXRF data through linear regression models.
\end{abstract}

Index terms: pXRF; soil moisture; soil texture; soil organic matter; prediction models.

\begin{abstract}
RESUMO
A espectrometria portátil de fluorescência de raios-X (pXRF) tem sido útil em todo o mundo para determinar o teor dos elementos no solo em condições de campo e de laboratório. No entanto, os resultados obtidos em campo podem ser influenciados por vários fatores, como umidade (U), textura (T) e matéria orgânica do solo (MOS). Assim, o objetivo deste trabalho foi criar modelos matemáticos lineares para a conversão dos teores dos elementos obtidos por pXRF em campo para resultados obtidos em laboratório, i.e., na Terra Fina Seca ao Ar (TFSA), utilizando U, T e MOS como variáveis auxiliares, uma vez que elas influenciam as leituras. As análises com pXRF foram realizadas em 12 perfis de solo com diferentes materiais de origem, seguidas por coleta de 59 amostras. Leituras com pXRF foram realizadas também em laboratório em amostras de TFSA. Os dados de pXRF obtidos em campo foram utilizados sozinhos ou combinados aos dados de $U, T$ e MOS como variáveis auxiliares, para criar modelos de regressão linear para predição dos resultados de pXRF em TFSA. A acurácia dos modelos foi calculada pelo método leave-one-out cross-validation. À exceção de elementos mais leves, as leituras de campo com pXRF subestimaram o teor total dos elementos. Modelos de predição incluindo T apresentaram maior acurácia na predição de $\mathrm{Al}_{2} \mathrm{O}_{3^{\prime}}, \mathrm{SiO}_{2^{\prime}} \mathrm{V}$, $\mathrm{Ti}$ e $\mathrm{Zr}$, enquanto a predição dos teores de $\mathrm{Fe}$ e $\mathrm{K}_{2} \mathrm{O}$ foi insensível à adição das variáveis auxiliares. A melhora relativa (MR) nos modelos de predição foi maior nas predições de $\mathrm{SiO}_{2}(\mathrm{~T}+\mathrm{MOS}: \mathrm{MR}=22,29 \%), \mathrm{V}(\mathrm{U}+\mathrm{T}: \mathrm{MR}=18,90 \%)$ e Ti (T+MOS: $\left.\mathrm{MR}=11,18 \%\right)$. Este trabalho demonstrou que é possível a correção dos dados de pXRF obtidos em campo através de modelos de regressão linear.
\end{abstract}

Termos para indexação: pXRF; umidade do solo; textura do solo; matéria orgânica do solo; modelos de predição.

\section{INTRODUCTION}

$\mathrm{X}$-ray fluorescence is a technique capable of providing quantitative data on the content of chemical elements in the analyzed material (Potts; West, 2008). This technique has been used in different branches of science, such as geochemistry, archeology, forensic science and soil science (Ribeiro et al., 2017; Weindorf; Bakr; Zhu, 2014). 
In this technique, a source of energy that emits X-rays hit the atoms of the analyzed material, making electrons to move from inner to outer orbits. Following on, electrons move back to their original orbit emitting energy in the form of fluorescence. Each chemical element emits a characteristic fluorescence when the electron returns to its original orbit, enabling the element identification. The intensity of the fluorescence detected determines the content of that element in the sample (Weindorf; Bakr; Zhu, 2014).

More recently, the portable X-ray fluorescence spectrometer (pXRF) has become a fast, cost-effective and environmentally friendly alternative for the determination of elemental contents in both field and laboratory conditions. pXRF can provide results in a shorter time, with minimal sample preparation and is a non-destructive method (Parsons et al., 2013; Schneider et al., 2016; Weindorf; Bakr; Zhu, 2014). This technique has facilitated different studies, such as evaluation of soil contamination by heavy metals, pedogenesis, soil chemistry, salinity and mapping, among others (Aldabaa et al., 2015; Mancini et al., 2019a, 2019b; O'Rourke et al., 2016; Sharma et al., 2014; Silva et al., 2017; Stockmann et al., 2016a; Weindorf et al., 2015).

However, works have reported that pXRF field data for many elements differ from those obtained under laboratory conditions, i.e, in air-dried fine earth (Silva et al., 2018; Stockmann et al., 2016b), mainly due to differences in moisture, texture, soil organic matter content, and sample roughness (Weindorf; Bakr; Zhu, 2014). This may constrain the use of field data, raising the need for correction of such results.

It is known that soil moisture (M) can absorb or disperse incident X-rays, influencing the results obtained by the equipment (Bastos; Melquiades; Biasi, 2012; Ge; Lai; Lin, 2005; Ribeiro et al., 2018; Sahraoui; Hachicha, 2017; Santana et al., 2019). Soil texture (T) can be associated with soil chemical and mineralogical composition and is capable of influencing various other soil attributes, such as cation exchange capacity, water infiltration rate and porosity, among others (Resende et al., 2014). Soil organic matter (SOM), in turn, promotes many benefits for soils, such as increasing water availability and presents great amounts of $\mathrm{C}, \mathrm{H}$, and $\mathrm{O}$; however, SOM can attenuate the X-ray beams, causing decreasing contents of elements detected by pXRF (Hudson, 1994; Ravansari; Lemke, 2018; Shand; Wendler, 2014).

Knowing the factors that may cause interference in the pXRF readings is extremely important for the correction of the field data obtained. Since soil organic matter is concentrated in the soil surface, some soil classes present a texture gradient in depth and that greater depths tend to maintain soil moisture for a longer time (Resende et al., 2014), the readings carried out with pXRF directly in the field are subject to reading variations caused by these factors (Stockmann et al., 2016a), which may hindrance works whose pXRF analyses have been conducted in both field and lab. Therefore, to demonstrate that it is possible to convert results of field analyses into those obtained in the lab may be very useful for researchers across the world, avoiding the necessity of analyzing the same sample in the field and in the lab. Furthermore, the influence of these soil properties may be variable according to the different elements, but deeper investigations are yet to be carried out in tropical conditions, especially regarding SOM and $\mathrm{T}$, which have not been evaluated yet.

Thus, the objectives of this study were to create and evaluate mathematical models capable of predicting the content of $\mathrm{Al}, \mathrm{Ca}, \mathrm{Fe}, \mathrm{K}, \mathrm{Si}, \mathrm{V}, \mathrm{Ti}$ and $\mathrm{Zr}$ obtained by pXRF in lab conditions (air-dried fine earth - ADFE) based on pXRF readings conducted in the field, and to assess the influence of M, T and SOM on the prediction of each element evaluated. The hypothesis of this work is that $\mathrm{M}$, $\mathrm{T}$, and SOM can help in the correction of the pXRF results obtained in the field, being possible to convert them into lab-obtained $\mathrm{pXRF}$ results without requiring other $\mathrm{PXRF}$ analyses in the lab.

\section{MATERIAL AND METHODS}

\section{Study area and sample collection}

The study area is located in Lavras, Minas Gerais, Brazil, between latitudes 7,650,808 and 7,651,674 mS and longitudes 500,031 and 492,189 $\mathrm{mW}$, zone $23 \mathrm{~K}$. The climate of the region has annual average temperature and precipitation of $20.4{ }^{\circ} \mathrm{C}$ and $1,460 \mathrm{~mm}$, respectively (Dantas; Carvalho; Ferreira, 2007), classified as Cwa (subtropical with dry winter and rainy summer) according to the Köppen climate classification.

The municipality of Lavras is geologically located at the southern edge of the São Francisco Craton. According to Curi et al. (1990) and Quéméneur et al. (2002), in the region it is common to find gneisses (leuco and mesocratic) cut by mafic rock dikes, represented mainly by gabbro and gabbronorite, while quartzites predominate in the areas of higher altitudes.

The evaluated soils encompassed these different parent materials as described in Table 1, such as the soil 
classes and sampled horizons. For this work, 12 soil profiles were described, 59 soil horizons were sampled during two consecutive days within the dry season to assure the actual moisture condition for all soil profiles. Soil profiles were classified at the second and fourth taxonomic levels according to the Brazilian Soil Classification System (Santos et al., 2018) and the US Soil Taxonomy (Soil Survey Staff, 2014), respectively (Table 1). At least one soil profile was described and sampled for each soil class. The main horizons were analyzed in situ, including: A, B, C, and $\mathrm{Cr}$ for mineral soils and $\mathrm{H}$ (or $\mathrm{O}$ horizon per Soil Taxonomy) for organic soils.

\section{Soil analyses}

The methodological sequence of field and laboratory procedures and the different analyses performed can be seen in Figure 1. First, soil profiles were excavated and the horizons were separated. Then, pXRF analyses were performed in each soil horizon (Table 1) directly on the soil profile wall in the field (pXRF field) (Figure 1), in three places of the same soil horizon, with ca. $10 \mathrm{~cm}$ (horizontally) between the scanning positions. The final pXRF result was obtained by averaging the three scanning results. Then, samples from each horizon were collected from the soil profiles, at the places where the scannings were conducted, in order to determine soil moisture and perform the subsequent lab analyses. For pXRF analysis in the laboratory, a portion (ca. $50 \mathrm{~g}$ ) of each sample was air-dried, sieved at $2 \mathrm{~mm}$ (air-dried fine earth - ADFE) and analyzed by pXRF (pXRF ADFE) by directly placing the equipment aperture at the surface of the samples, making sure the amount of the sample was thick enough (ca. 2 $\mathrm{cm}$ ) to avoid the X-ray beams both passing through it and reaching the base of the Petri dish containing the sample. A Bruker ${ }^{\circledR}$ pXRF model S1 Titan 600 LE containing the software Geochem was used to perform the analyses and yielding the elemental results. This equipment contains a $50 \mathrm{keV}$ and $100 \mu \mathrm{A} \mathrm{X}$-ray $\mathrm{Rh}$ tube with silicon drift detector (SSD) $<145 \mathrm{eV}$.

Table 1: Classification, horizons and parent material of the soils sampled in Lavras, Minas Gerais, Brazil.

\begin{tabular}{|c|c|c|c|c|}
\hline Parent material & $\begin{array}{c}\text { Brazilian Soil } \\
\text { Classification System }\end{array}$ & US Soil Taxonomy & Sampled horizons & $\begin{array}{l}\text { Total number of } \\
\text { samples }\end{array}$ \\
\hline \multirow{4}{*}{ Quartzite } & Litholic Neosol & Lithic Ustorthent & $\mathrm{A}, \mathrm{C}, \mathrm{Cr}$ & \multirow{4}{*}{17} \\
\hline & Regolithic Neosol & Typic Ustorthent & $\mathrm{A}, \mathrm{Cr}$ & \\
\hline & Haplic Cambisol & Typic Dystrustept & $\mathrm{A}, \mathrm{B}, \mathrm{C}, \mathrm{Cr}$ & \\
\hline & Yellow Latosol & Xanthic Hapludox & $A, B$ & \\
\hline \multirow{4}{*}{ Gabbro } & Regolithic Neosol & Typic Ustorthent & $\mathrm{A}, \mathrm{Cr}$ & \multirow{4}{*}{10} \\
\hline & Haplic Cambisol & Typic Ustorthent & $A, B, C$ & \\
\hline & Red Nitosol & Rhodic Kandiudult & $A, B, C$ & \\
\hline & Red Latosol & Anionic Acrudox & $A, B$ & \\
\hline \multirow{9}{*}{ Gneiss } & Litholic Neosol & Lithic Ustorthent & $\mathrm{A}, \mathrm{C}, \mathrm{Cr}$ & \multirow{9}{*}{24} \\
\hline & Regolithic Neosol & Typic Ustorthent & $\mathrm{A}, \mathrm{Cr}$ & \\
\hline & Haplic Cambisol & Typic Dystrustept & $\mathrm{A}, \mathrm{B}, \mathrm{C}, \mathrm{Cr}$ & \\
\hline & Yellow Argisol & Inceptic Hapludult & $A, B, C$ & \\
\hline & Red-Yellow Argisol & Typic Hapludult & $A, B, C$ & \\
\hline & Red Argisol & Typic Rhodudult & $A, B, C$ & \\
\hline & Yellow Latosol & Xanthic Hapludox & $A, B$ & \\
\hline & Red-Yellow Latosol & Typic Hapludox & $A, B$ & \\
\hline & Red Latosol & Rhodic Hapludox & $A, B$ & \\
\hline Mineral sediments & Haplic Gleysol & Typic Endoaquent & $A, C$ & 2 \\
\hline Organic sediments & Haplic Organosol & Typic Udifolist & $\mathrm{A}, \mathrm{H}$ & 6 \\
\hline Total & & & & 59 \\
\hline
\end{tabular}




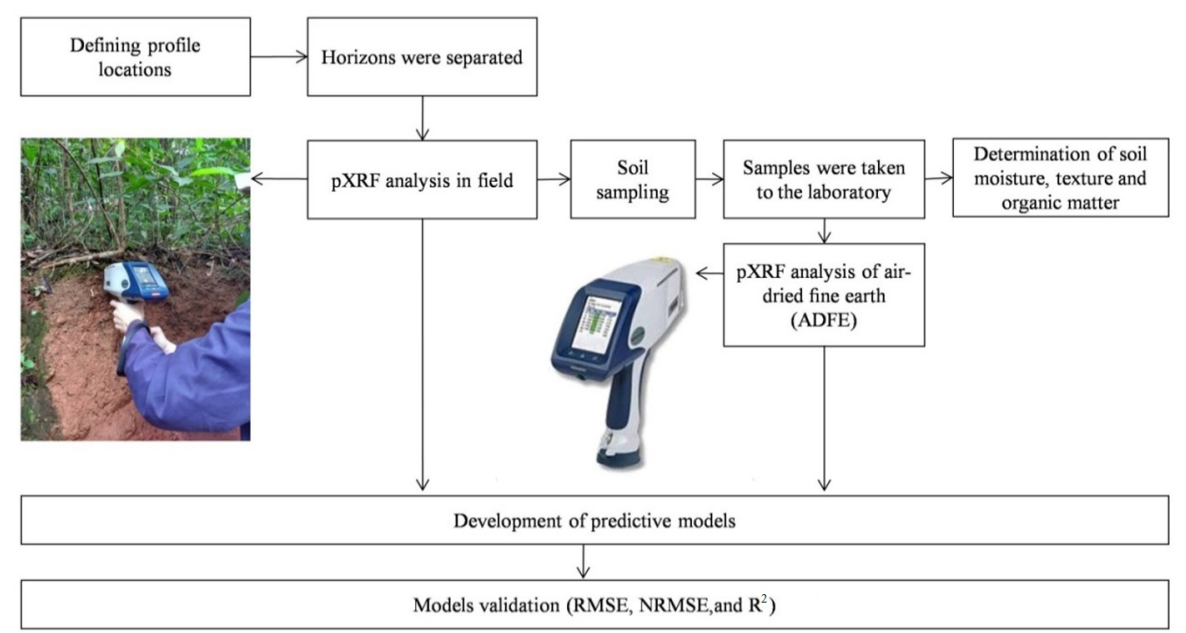

Figure 1: Workflow of the procedures conducted in this study.

Field and laboratory $\mathrm{pXRF}$ readings were performed in triplicate during $60 \mathrm{~s}$ in dual soil mode. To verify the quality of data generated by the equipment, two National Institute of Standards and Technology (NIST) certified samples, 2710a and 2711a, and one sample certified by the pXRF manufacturer (Check Sample) were used. The pXRF results were compared with the certified contents for the elements used in this study. The recovery values (pXRF content / certified content) for 2710a, 2711a and Check Sample were, respectively: $\mathrm{Al}_{2} \mathrm{O}_{3}-0.96 / 1.19 / 0.87 ; \mathrm{SiO}_{2}$ 0.94/1.08/0.88; Fe - 0.43/0.70/0.89; $\mathrm{K}_{2} \mathrm{O}-0.40 / 0.59 / 0.86$; $\mathrm{CaO}-0.18 / 0.73 / 0$; $\mathrm{Ti}-0.51 / 0.73 / 0 ; \mathrm{Zr}-0.98 / 0 / 0$. The zero value indicates that either there was no quantification in the reference sample or the element was not detected by $\mathrm{pXRF}$.

To determine soil moisture (M), samples were weighted (Wet Mass - WM) and oven-dried at $105^{\circ} \mathrm{C}$ during 24 hours. After this period, the samples were again weighted to determine the dry mass (DM). Thus, soil moisture (\%) was calculated using Equation 1. The collected samples were also subjected to laboratory analysis to determine texture (Gee; Bauder, 1986) and soil organic matter (Walkley; Black, 1934).

$M \%=\frac{(W M-D M)}{W M} * 100$

\section{Statistical analyses}

For the prediction of the pXRF results obtained in the laboratory (ADFE) based on the results obtained in the field for each element, linear regression models were created using different combinations of pXRF results obtained in the field with the independent variables $\mathrm{M}, \mathrm{T}$ and SOM, according to Equations 2, 3, 4, 5, 6, 7, 8 and 9.

$$
\begin{aligned}
& y=a 1 x 1+b \\
& y=a 1 x 1+a 2 M+b \\
& y=a 1 x 1+a 2 T+b \\
& y=a 1 x 1+a 2 S O M+b \\
& y=a 1 x 1+a 2 M+a 3 S O M+b \\
& y=a 1 x 1+a 2 T+a 3 S O M+b \\
& y=a 1 x 1+a 2 M+a 3 T+b \\
& y=a 1 x 1+a 2 M+a 3 T+a 4 S O M+b
\end{aligned}
$$

where $a$ is the slope, $y$ is the content of each element to be predicted in the ADFE, $x$ is the content of each element obtained in the field by $\mathrm{pXRF}, \mathrm{M}$ is soil moisture, $\mathrm{T}$ is texture (sand, silt, and clay contents) and SOM is the soil organic matter content.

The accuracy of the predictions of each element content in the ADFE was calculated by the leave-one-out cross-validation method of the "caret" package (Kuhn et al., 2018) in the R software (R Core Team, 2019), through calculation of the following parameters: $\mathrm{R}^{2}$, root mean square error (RMSE) (Equation 10) and normalized RMSE (NRMSE) (Equation 11). 


$$
\begin{aligned}
& \text { RMSE }=\sqrt{\frac{1}{n} \sum_{i=1}^{n}(e i-m i)^{2}} \\
& N R M S E=\frac{R M S E}{\sigma}
\end{aligned}
$$

where $n$ is the number of observations, and $i$ is the element content predicted by pXRF in ADFE through the models, $e i$ is the estimated content of elements, and $m i$ is the content of elements obtained by pXRF in ADFE.

In addition to these parameters, the relative improvement (RI) (Equation 12) of the models in relation to the simple linear model of Equation 2 was calculated. Thus, it was possible to define if the auxiliary variables $\mathrm{M}, \mathrm{T}$ and SOM contribute to the prediction of the content of each element obtained by $\mathrm{pXRF}$ in ADFE, based on the contents obtained by pXRF in the field.

$$
R I=\frac{R M S E_{\text {field }}-R M S E_{\text {with treatments }}}{R M S E_{\text {field }}} * 100
$$

\section{RESULTS AND DISCUSSION}

\section{Characterization of the soil moisture, texture and organic matter}

The values of minimum, maximum, mean, standard deviation (SD), and coefficient of variation (CV) for texture (clay, silt, and sand contents), $\mathrm{M}$ and SOM of the studied soils are presented in Table 2. The substantial range of the values reflects the different soil classes and the parent materials in which the samples were collected.

Table 2: Minimum, maximum, mean, standard deviation (SD), and coefficient of variation (CV) obtained for soil texture (clay, silt, and sand contents), moisture (M) and organic matter (SOM) for the studied soils.

\begin{tabular}{cccccc}
\hline $\begin{array}{c}\text { Soil } \\
\text { property }\end{array}$ & \multicolumn{6}{c}{ Minimum Maximum } & Mean & SD & CV \\
\hline Clay (\%) & 5 & 70 & 32 & 18.3 & 2.4 \\
Silt (\%) & 5 & 59 & 26 & 12.9 & 1.7 \\
Sand (\%) & 14 & 68 & 42 & 13.7 & 1.8 \\
SOM (\%) & 0.1 & 14.1 & 1.7 & 2.2 & 0.3 \\
M (\%) & 0.5 & 37.5 & 13.6 & 10.6 & 1.4 \\
\hline
\end{tabular}

The highest SD values were obtained for texture, as there is great variability between the soil classes, horizons, parent materials (Resende et al., 2014) (Figure 2). Additionally, different degrees of weathering and erosion rate of soils influence soil texture (Zhang et al., 2019), helping to explain the results.

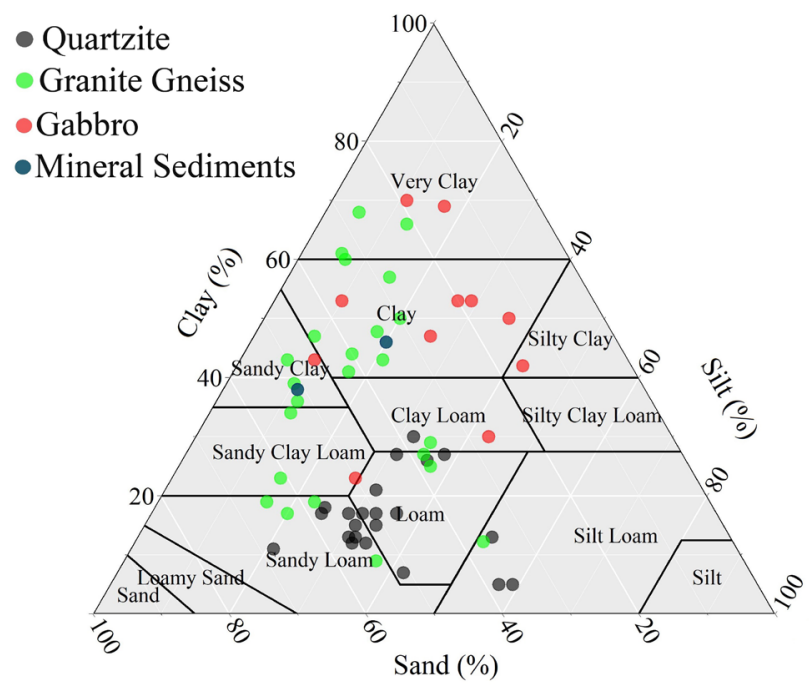

Figure 2: Textural classes of the samples collected in soils developed from different parent materials.

In general, the clay content increases in the following order: quartzite $<$ gneiss $<$ gabbro. The higher the quartz content in the parent material the smaller the soil clay content, which is associated with the high quartz resistance to weathering mostly present in the sand particle size fraction.

The variation in SOM contents (Figure 3) was probably caused by different land uses and practices of soil management (Foley et al., 2005), as well as the depth of the sample, clay content, mineralogy, climate, moisture regime, among others (Resende et al., 2014). The highest contents of SOM were observed in the Haplic Organosol (Typic Udifolist), due to the paludization pedogenetic process (Santos et al., 2018). For the other soil classes, the highest SOM content was observed in the superficial horizon. The soils derived from quartzite presented lower SOM contents probably due to their higher sand content and the dominance of sparse grasses in the area, causing little deposition of organic matter. The soils derived from gneiss and gabbro, due to their higher clay contents among other factors, presented higher accumulation of SOM. 


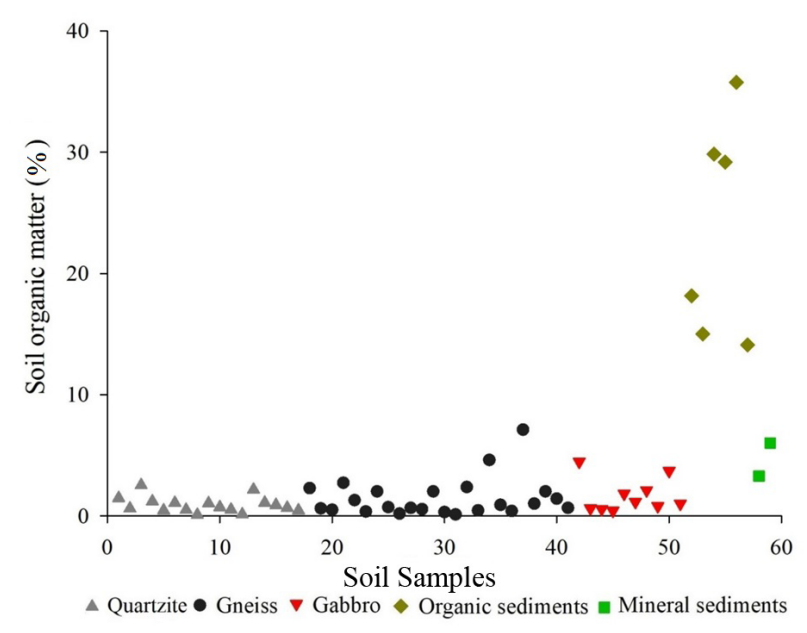

Figure 3: Soil organic matter content in soil samples derived from different parent materials.

Soil moisture (Figure 4) varied according to clay fraction content, SOM content, climatic conditions and land use, and its availability may still be influenced by soil management (Centurion; Andrioli, 2000). The highest moisture content was observed in the Haplic Organosol (Typic Udifolist), related to its position in the landscape and to the higher SOM content, since all the samples were collected in two consequent days within the dry season. Conversely, the soils derived from quartzite, mostly due to their texture rich in sand and lower SOM contents, presented the lowest moisture content.

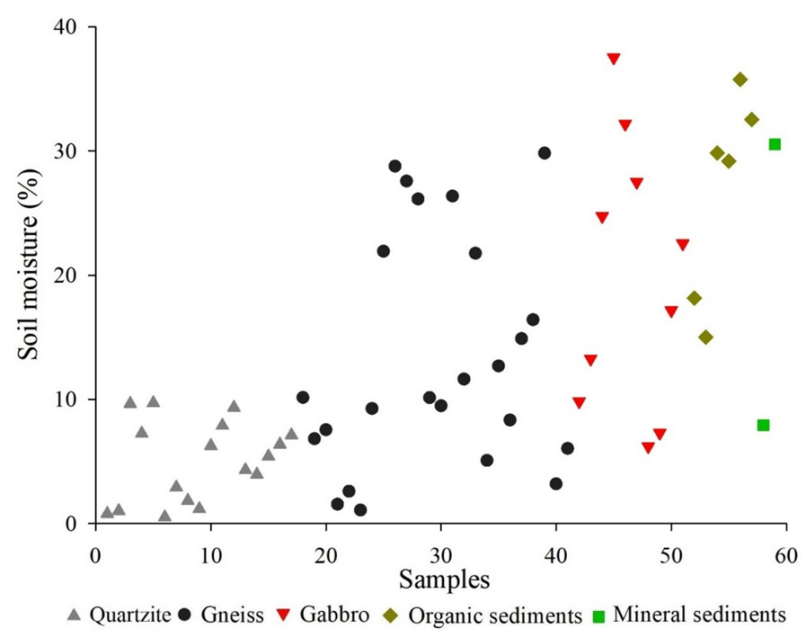

Figure 4: Moisture content in soils derived from quartzite, gneiss, gabbro and organic and mineral sediments.

\section{Variation of soil elemental contents}

The soils developed from gabbro presented, on average, higher Fe contents compared to the soils developed from other parent materials (Table 3). This is primarily because the parent rock had a higher Fe content (Monroe; Wicander, 2017) and Fe tends to accumulate in soils. Conversely, quartzite-derived soils presented the highest $\mathrm{SiO}_{2}$ contents compared to the others, because this rock is basically composed of quartz $\left(\mathrm{SiO}_{2}\right)$, a very resistant mineral to weathering (Resende et al., 2019). Also, relationships between the content of certain chemical elements and the different textural fractions of the soil can be made (Zhu; Weindorf; Zhang, 2011). In tropical soils, for instance, greater contents of $\mathrm{SiO}_{2}$ tend to correspond to soils rich in quartz $\left(\mathrm{SiO}_{2}\right)$, dominantly found in greater contents in soils rich in sand (Kämpf; Maques; Curi, 2012; Silva et al., 2019).

The elemental contents of the soil samples varied according to field or laboratory - ADFE (Figures 5 and 6). In general, the contents of all elements or oxides in ADFE were higher than those obtained in the field, with the exception of light-weight elements. This may have occurred because light-weight elements are more influenced by moisture, as also reported by Ribeiro et al. (2018).

The percentage of samples that presented higher contents in ADFE compared to contents of the field analysis was $97 \%$ for $\mathrm{CaO}, \mathrm{Fe}$, and $\mathrm{Ti}, 93 \%$ for $\mathrm{K}_{2} \mathrm{O}$, $88 \%$ for $\mathrm{SiO}_{2}, 86 \%$ for $\mathrm{Zr}, 57 \%$ for $\mathrm{Al}_{2} \mathrm{O}_{3}$, and $71 \%$ for V. Stockmann et al. (2016a; 2016b), evaluating the elemental contents obtained in both field and laboratory (ADFE) conditions by pXRF in Australia, observed that, in general, the contents of $\mathrm{Fe}, \mathrm{K}$ and $\mathrm{Ca}$ were higher in ADFE than those obtained in the field, as found in this work (Figure 6).

\section{Prediction models}

The values of $\mathrm{R}^{2}$ adj corresponding to the adjustment of the linear models to predict $\mathrm{Al}_{2} \mathrm{O}_{3}, \mathrm{CaO}, \mathrm{Fe}, \mathrm{K}_{2} \mathrm{O}$, $\mathrm{SiO}_{2}, \mathrm{~V}, \mathrm{Ti}$, and $\mathrm{Zr}$ in ADFE from the results of pXRF field analyses, considering the influence of $\mathrm{M}, \mathrm{T}$ and $\mathrm{SOM}$ are presented in Figure 7. For $\mathrm{Fe}_{\mathrm{ADFE}}$ and $\mathrm{K}_{2} \mathrm{O}_{\text {ADFE }}$ predictions, slight differences in $\mathrm{R}_{\text {adj }}^{2}$ were observed when adding the auxiliary variables to the models. Stockmann et al. (2016b) reported the small effect of moisture on Fe content obtained by $\mathrm{pXRF}$, similarly to reports of Ribeiro et al. (2018) and the findings of this work. However, here it was noticed that $\mathrm{T}$ and SOM also have a very low effect on Fe results. 
Table 3: Mean contents of elements $\left(\mathrm{mg} \mathrm{kg}^{-1}\right)$ obtained by portable X-ray fluorescence (pXRF) spectrometer in soils in the field and in air-dried fine earth (ADFE) samples.

\begin{tabular}{cccrrrrrrc}
\hline Parent Material & Analysis & $\mathrm{Al}_{2} \mathrm{O}_{3}$ & \multicolumn{1}{c}{$\mathrm{CaO}$} & \multicolumn{1}{c}{$\mathrm{Fe}$} & \multicolumn{1}{c}{$\mathrm{K}_{2} \mathrm{O}$} & $\mathrm{SiO}_{2}$ & \multicolumn{1}{c}{$\mathrm{V}$} & $\mathrm{Ti}$ & $\mathrm{Zr}$ \\
\hline \multirow{2}{*}{ Quartzite } & Field & 86727 & 242 & 8686 & 12554 & 398872 & 14 & 2116 & 218 \\
& ADFE & 84360 & 1201 & 14041 & 17433 & 520871 & 6 & 2990 & 243 \\
\hline \multirow{2}{*}{ Gneiss } & Field & 187076 & 470 & 25649 & 3795 & 262297 & 10 & 3402 & 156 \\
& ADFE & 186952 & 1144 & 36695 & 6710 & 290484 & 14 & 5046 & 179 \\
\hline \multirow{2}{*}{ Gabbro } & Field & 140314 & 595 & 82237 & 1986 & 121544 & 123 & 4393 & 122 \\
& ADFE & 135228 & 1786 & 131419 & 3151 & 185700 & 134 & 8943 & 205 \\
\hline \multirow{2}{*}{ Mineral sediments } & Field & 150515 & 995 & 68055 & 971 & 168046 & 54 & 2594 & 155 \\
& ADFE & 159686 & 1074 & 80623 & 1695 & 233740 & 108 & 10085 & 188 \\
\hline \multirow{2}{*}{ Organic sediments } & Field & 104472 & 770 & 18864 & 6016 & 269845 & 11 & 5463 & 157 \\
& ADFE & 120351 & 75 & 27293 & 8697 & 395594 & 8 & 5340 & 205 \\
\hline
\end{tabular}
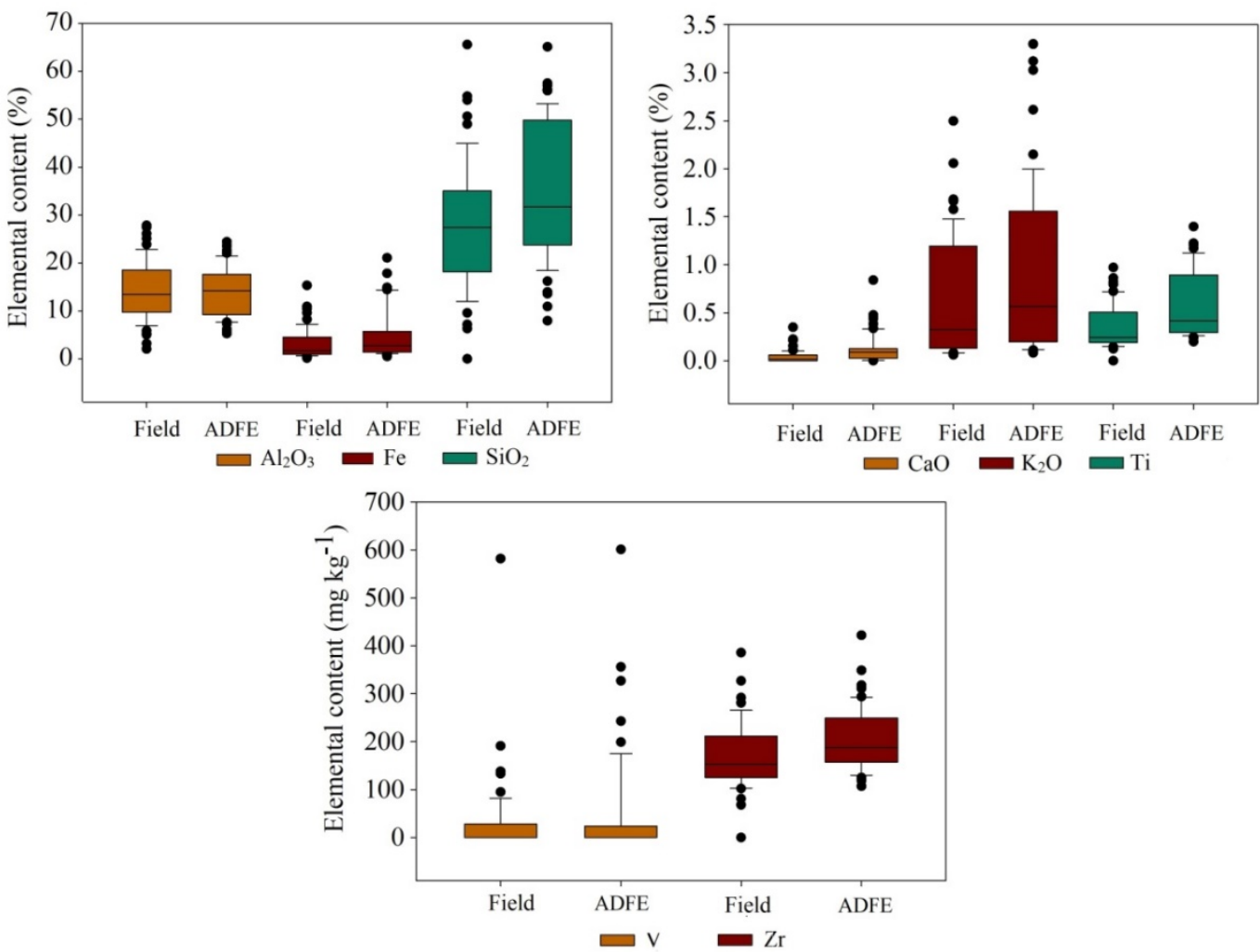

Figure 5: Elemental content obtained by portable X-ray fluorescence (pXRF) spectrometer in soils in the field and in $\mathrm{ADFE}$ for $\mathrm{Al}_{2} \mathrm{O}_{3^{\prime}} \mathrm{Fe}, \mathrm{SiO}_{2}, \mathrm{CaO}, \mathrm{K}_{2} \mathrm{O}, \mathrm{Ti}, \mathrm{V}$, and $\mathrm{Zr}$.

The models that considered the soil texture as an auxiliary variable delivered higher values of $\mathrm{R}^{2}$ adj for the prediction of $\mathrm{SiO}_{2}$ and $\mathrm{V}$. $\mathrm{SiO}_{2}$ predictions reached $\mathrm{R}_{\text {adj }}^{2}$ of 0.60 using only the data obtained in the field, but it increased to 0.76 when adding soil texture to the prediction models. The increment of the $\mathrm{R}_{\text {adj }}^{2}$ values with the addition of the texture data can be explained by the fact that quartz, composed of $\mathrm{SiO}_{2}$, is the predominant component in the sand fraction of Brazilian 
soils (Alves et al., 2013; Araujo et al., 2014). Importantly, the changes in soil moisture did not significantly implied changes in $\mathrm{R}_{\text {adj }}^{2}$ for $\mathrm{SiO}_{2}$ contents, contrary to the findings of Ribeiro et al. (2018). SOM did not improve $\mathrm{SiO}_{2}$ models either.

For $\mathrm{V}, \mathrm{R}_{\text {adj }}^{2}$ increased from 0.73 to 0.80 with addition of texture, with a small increase by adding only moisture ( 0.73 to 0.75 ) and no improvement when adding soil organic matter as an auxiliary variable. $V$ presents dynamics similar to Fe and Fe secondary oxide minerals (Aide, 2005; Kabata-Pendias, 2010; Martin; Kaplan, 1998). $\mathrm{V}^{3+}$ tends to accumulate along weathering and it can be incorporated into octahedral sites of kaolinite, gibbsite, hematite, and goethite, which are dominant in the clay fraction of most Brazilian soils (Marques et al., 2004). Differences in $\mathrm{R}^{2}$ values were minimal for $\mathrm{K}_{2} \mathrm{O}$ and $\mathrm{Fe}$ prediction by adding moisture, texture and soil organic matter. For $\mathrm{K}_{2} \mathrm{O}$, the model
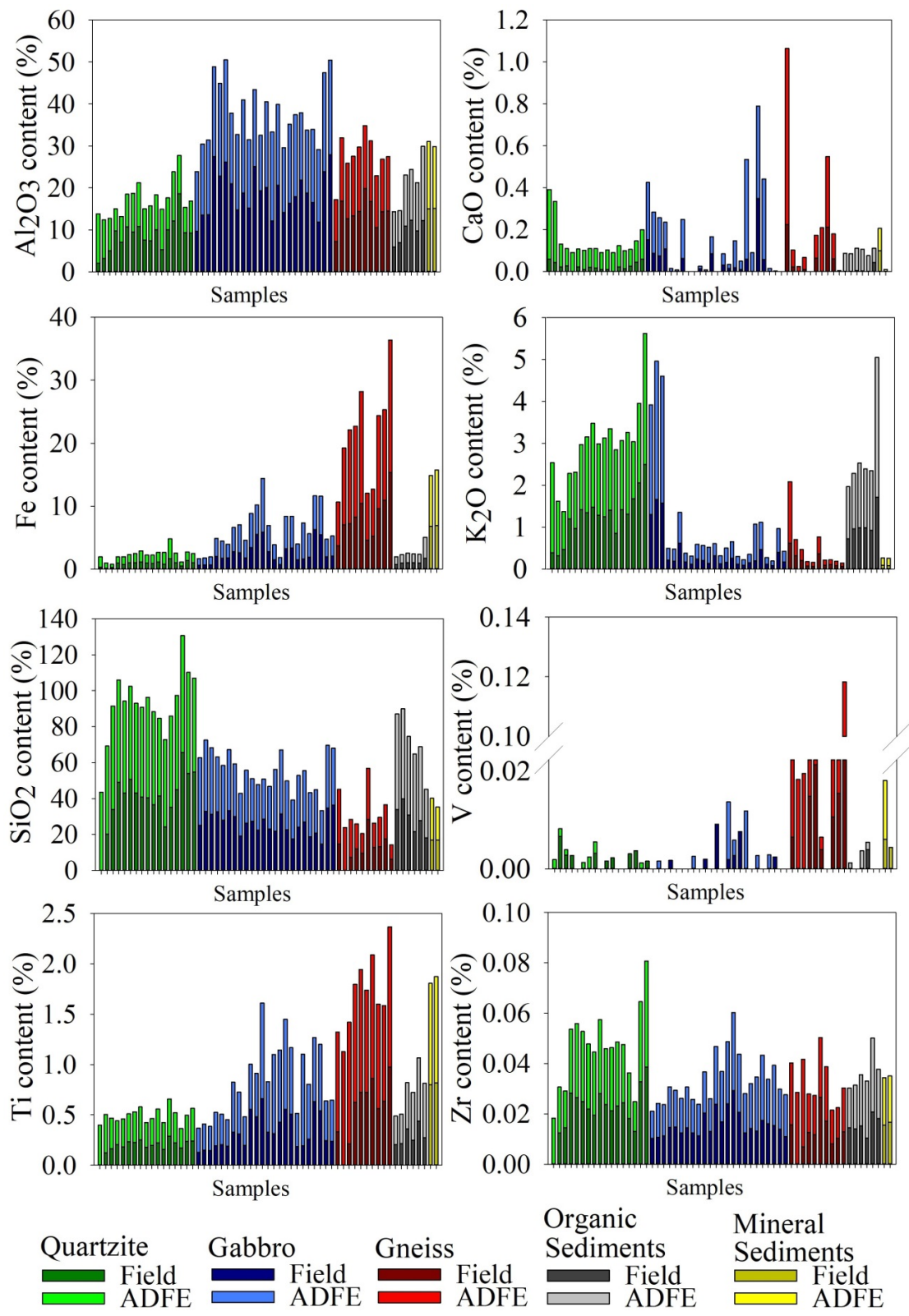

Figure 6: Field and laboratory (air-dried fine earth - ADFE) pXRF results of tropical soils for $\mathrm{Al}_{2} \mathrm{O}_{3^{\prime}} \mathrm{CaO}, \mathrm{Fe}, \mathrm{K}_{2} \mathrm{O}$, $\mathrm{SiO}_{2}, \mathrm{~V}, \mathrm{Ti}$, and $\mathrm{Zr}$. 


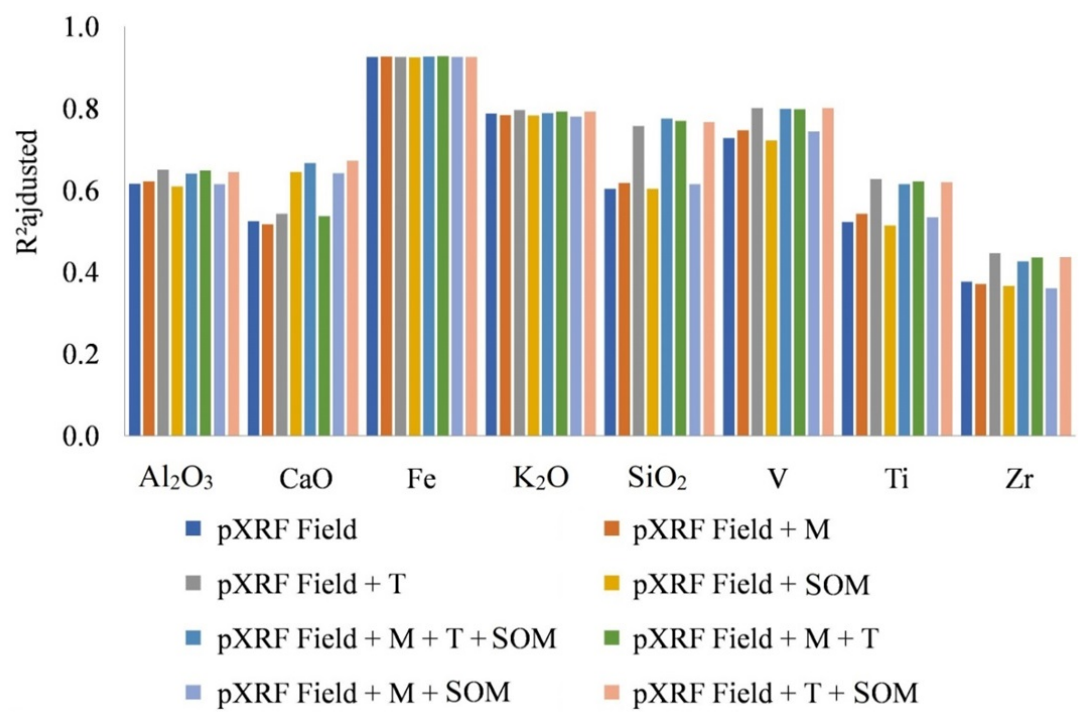

Figure 7: $\mathrm{R}^{2}$ adj corresponding to the adjustment of linear models for the prediction of the $\mathrm{Al}_{2} \mathrm{O}_{3^{\prime}}, \mathrm{CaO}, \mathrm{Fe}, \mathrm{K}_{2} \mathrm{O}, \mathrm{SiO}_{2^{\prime}}$ $\mathrm{Ti}, \mathrm{V}$, and $\mathrm{Zr}$ contents obtained in the air-dried fine earth (ADFE) from the results of the pXRF analyses conducted in field in association with moisture (M), texture (T) and soil organic matter (SOM).

with $\mathrm{pXRF}$ field data coupled with texture provided $\mathrm{R}^{2}$ adj of 0.80 compared with 0.79 using only pXRF field data. For $\mathrm{Fe}$, all the models presented minimal variation, with all the $\mathrm{R}_{\text {adj }}^{2}$ achieving values of 0.93 .

The model for $\mathrm{Al}_{2} \mathrm{O}_{3}$ prediction obtained in laboratory with addition of SOM presented the smallest $\mathrm{R}_{\text {adj }}^{2}(0.61)$ when compared to the models generated from the addition of texture and moisture. Although a small increase occurred when adding the two latter variables to the models, the $\mathrm{R}_{\text {adj }}^{2}$ values reached 0.65 and 0.62 , respectively. Texture and moisture, when combined with pXRF data, promoted the same result as the model using only pXRF and texture data. Soil moisture generally underestimates pXRF results (Bastos; Melquiades; Biasi, 2012; Hangen; Vieten, 2016; Lemiere et al., 2014), while texture may affect $\mathrm{pXRF}$ analyses due to the range of particle sizes and soil heterogeneity (Berger; Zou; Schleicher, 2009). For Ti prediction, when moisture and texture were added to the model, $\mathrm{R}_{\text {adj }}^{2}$ values varied from 0.52 to 0.54 and 0.63 , respectively. High and positive correlations $(0.78)$ were found by Zhu et al. (2011) between Ti and clay contents in temperate soils from USA, supporting the importance of texture for Ti prediction models.

For Zr prediction, $\mathrm{R}_{\text {adj }}^{2}$ values were the lowest among the evaluated elements. With the addition of texture, $\mathrm{R}_{\text {adj }}$ increased from 0.38 to 0.45 , unlike the inclusion of other variables that did not produce considerable improvements. Stockmann et al. (2016b), studying the pedogenesis of soils developed from different parent materials, verified an increase in $\mathrm{Zr}$ content with an increase in clay content. Since $\mathrm{Zr}$ is an element commonly found in very resistant minerals, its content tends to relatively increase with soil weathering. Curi and Franzmeier (1987) noted that claytextured soils ( $71 \%$ clay) developed from basalt showed an increase in soil $\mathrm{Zr}$ content relative to rock due to $\mathrm{Zr}$ presence in zircon, a weathering resistant mineral. Several studies have highlighted the influence of particle size on pXRF analysis (Berger; Zou; Schleicher, 2009; Parsons et al., 2013; Stockmann et al., 2016b; Zhu; Weindorf; Zhang, 2011). This is explained by the fact that larger particles in the soil may not represent the entire composition contained in the sample (Parsons et al., 2013).

\section{Models validation}

In general, good values of the validation parameters of the prediction models were achieved, reaching high $\mathrm{R}^{2}$ and low NRMSE and RMSE (Figures 8 and 9, and Table 4, respectively). For Fe, the high $\mathrm{R}^{2}$ value and the lowest value of NMRSE are notorious, showing that the prediction of $\mathrm{Fe}_{\mathrm{ADFE}}$ yields adequate results under different conditions. However, when analyzing RI (Table 4) for different models using different sets of variables, there is no considerable improvement. Thus, for Fe, only field data is capable to deliver accurate predictions of the values in ADFE, and it is not necessary to add other variables to the prediction models. This enables to perform these analyses even faster and more economical, since adding other variables would increase costs and time. 
For $\mathrm{SiO}_{2}$ and $\mathrm{V}$, the values of $\mathrm{R}^{2}$ were high (Figure 8) and together with the low NRMSE obtained (Figure 9), indicate a good performance of the model in comparison with most other elements. Also, $\mathrm{SiO}_{2}$ and $\mathrm{V}$ presented a higher RI among all groups, reaching $20.29 \%$ and $17.90 \%$, respectively, after adding only the texture as an auxiliary variable. Thus, addition of texture allows better predictions for $\mathrm{SiO}_{2}$ and $\mathrm{V}$ without the addition of other variables. For $\mathrm{K}_{2} \mathrm{O}, \mathrm{R}^{2}$ values were high $(0.77)$ and $\mathrm{RMSE}$ values were low and there were no remarkable distinctions regarding the addition of different variables to the models. Also, the highest RI was achieved with the addition of texture only $(1.28 \%)$. It is possible to state that, due to the small contribution of texture, the field data are sufficient for good predictions. The same happened for $\mathrm{Fe}$, where the RI values were mostly low and negative (-1.52\%), except for the model adding SOM and T (2.40\%).

Ti presented the highest $\mathrm{R}^{2}(0.60)$, with a considerable RI (11.18\%) in the models to which texture and soil organic matter were added. For $\mathrm{CaO}$, the highest $\mathrm{R}^{2}$ was 0.48 , however, the RMSE presented the highest value $(1.141,24)$ in relation to the other elements (Table 4 ). This was probably caused by some $\mathrm{pXRF}$ readings that did not detect $\mathrm{CaO}$ in one of the conditions (field or lab), drastically increasing RMSE. $\mathrm{Al}_{2} \mathrm{O}_{3}$ models presented values of $\mathrm{R}^{2}$ between 0.56 and 0.60 , not much different from other elements that obtained $\mathrm{R}^{2}$ near or higher than 0.80 , such as $\mathrm{Fe}, \mathrm{K}_{2} \mathrm{O}, \mathrm{SiO}_{2}$, and V. However, the RI for $\mathrm{Al}_{2} \mathrm{O}_{3}$ was negative for most models, especially by adding texture and SOM $(\mathrm{RI}=-5.28 \%)$, and when all variables were included $(\mathrm{RI}=-5.24 \%)$. Small positive RI values were obtained by adding only $\mathrm{M}(0.15 \%)$ and $\mathrm{M}+\mathrm{T}(0.97 \%)$ (Table 4).

For $\mathrm{Zr}$ validation, $\mathrm{R}^{2}$ was very low and NRMSE was very high. Therefore, it is not advisable to use these models to predict $\mathrm{Zr}_{\mathrm{ADFE}}$. Despite of that, it can be observed that adding texture produced a slight improvement over the initial model ranging from 0.30 to 0.35 , respectively, indicating that this variable has some positive interference in the prediction of $\mathrm{Zr}$ in the ADFE.

Most prediction models were strongly influenced by texture. In tropical soils, the higher sand content tend to positively correlate with $\mathrm{SiO}_{2}$ content, since this particle size fraction in most soils is dominated by quartz, composed by $\mathrm{SiO}_{2}$ (Kämpf; Marques; Curi, 2012; Silva et al., 2019). Thus, the use of texture in $\mathrm{SiO}_{2}$ (and in almost all the other) prediction models improved all statistical parameters evaluated in relation to models that did not use texture as an auxiliary variable. Moisture had less importance than texture in the accuracy improvement of the models, since the reduction in X-ray intensity is proportional to the increase of water content in the sample (Stockmann et al., 2016b). In these tropical soils, soil organic matter did not strongly affect the models, as opposite to the findings of Ravansari and Lemke (2018) in soils from Canada to which three organic materials were added and elemental contents were measured via $\mathrm{pXRF}$ after each organic material addition. It is important to reemphasize that both soil texture and organic matter are factors that directly influence soil moisture.

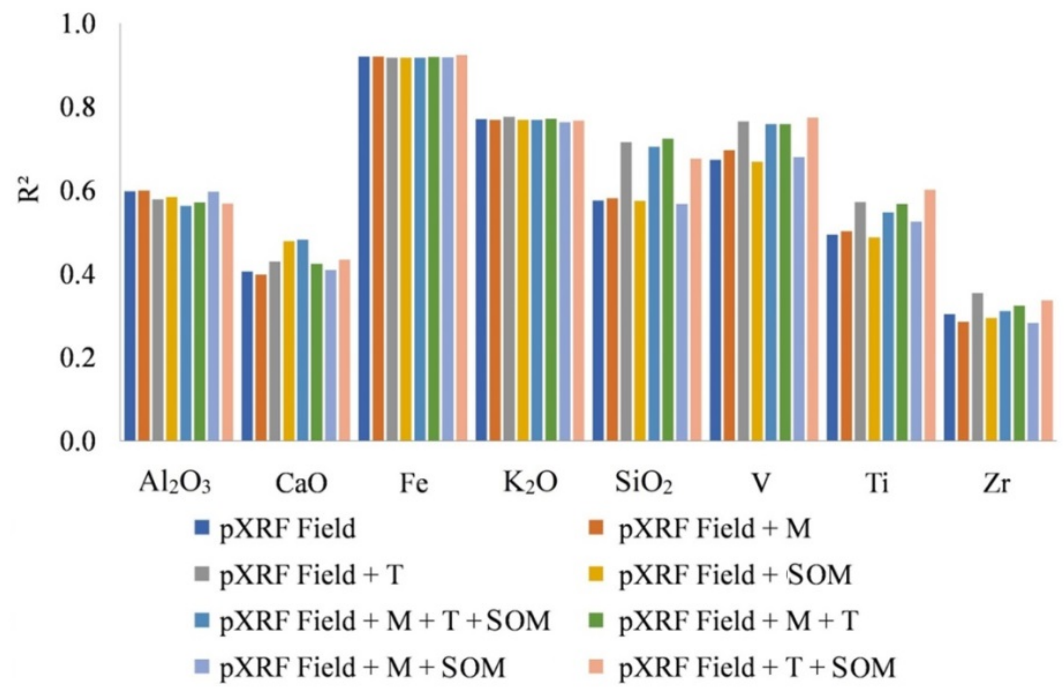

Figure 8: Coefficient of determination $\left(\mathrm{R}^{2}\right)$ corresponding to the validation of linear models for the prediction of $\mathrm{Al}_{2} \mathrm{O}_{3^{\prime}}$ $\mathrm{CaO}, \mathrm{Fe}, \mathrm{K}_{2} \mathrm{O}, \mathrm{SiO}_{2}, \mathrm{Ti}, \mathrm{V}$, and $\mathrm{Zr}$ contents obtained by portable X-ray fluorescence (pXRF) spectrometry on air-dried fine earth (ADFE) based on pXRF analysis in field associated with texture (T), moisture (M) and soil organic matter (SOM). 


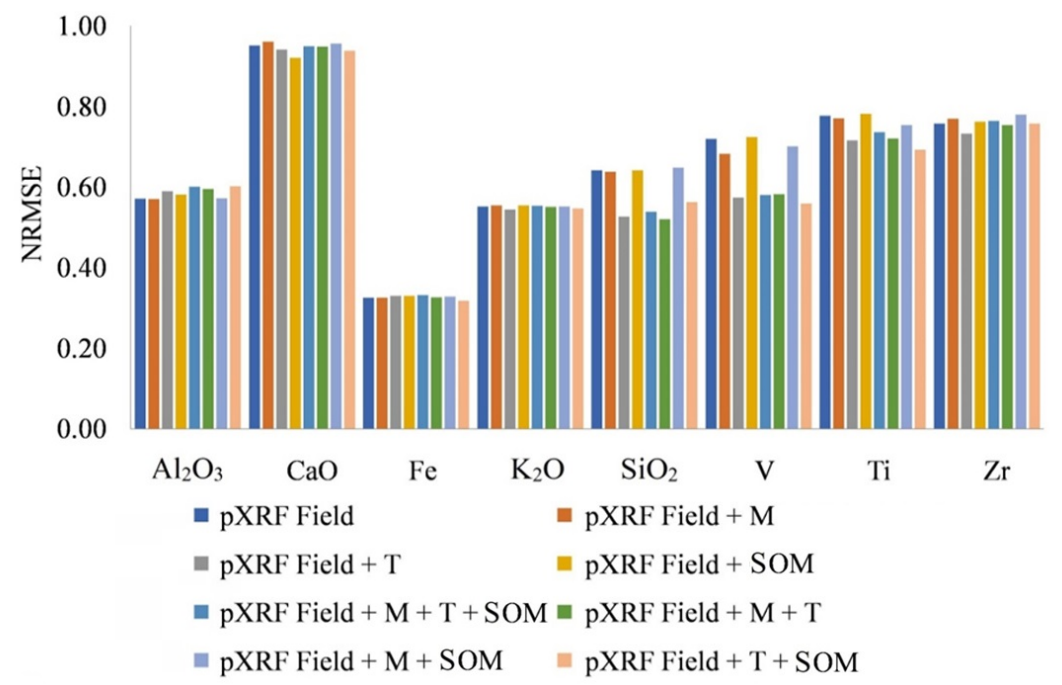

Figure 9: Normalized root mean square error (NRMSE) corresponding to the validation of linear models to predict $\mathrm{Al}_{2} \mathrm{O}_{3}, \mathrm{CaO}, \mathrm{Fe}, \mathrm{K}_{2} \mathrm{O}, \mathrm{SiO}_{2}, \mathrm{Ti}, \mathrm{V}$, and $\mathrm{Zr}$ contents obtained by portable X-ray fluorescence (pXRF) spectrometer in air-dried fine earth (ADFE) based on field pXRF analysis in field associated with texture (T), moisture (M) and soil organic matter (SOM).

Table 4: Root mean square error (RMSE) and relative improvement (RI) corresponding to the validation of models for the prediction of $\mathrm{Al}_{2} \mathrm{O}_{3}, \mathrm{CaO}, \mathrm{Fe}, \mathrm{K}_{2} \mathrm{O}, \mathrm{SiO}_{2}, \mathrm{~V}$, $\mathrm{Ti}$, and $\mathrm{Zr}$ contents of the air-dried fine earth (ADFE) by portable $x$-ray fluorescence ( $\mathrm{pXRF)}$ ) spectrometer based on field pXRF analysis associated with texture (T), moisture (M) and soil organic matter (SOM).

\begin{tabular}{|c|c|c|c|c|c|c|c|c|}
\hline Linear Regressions & $\mathrm{Al}_{2} \mathrm{O}_{3}$ & $\mathrm{CaO}$ & $\mathrm{Fe}$ & $\mathrm{K}_{2} \mathrm{O}$ & $\mathrm{SiO}_{2}$ & $\mathrm{~V}$ & $\mathrm{Ti}$ & $\mathrm{Zr}$ \\
\hline & \multicolumn{8}{|c|}{ RMSE (mg kg-1) } \\
\hline pXRF Field & 31500 & 1130 & 13261 & 4198 & 90836 & 69 & 2365 & 53 \\
\hline pXRF Field $+M$ & 31454 & 1141 & 13257 & 4217 & 90303 & 66 & 2347 & 54 \\
\hline pXRF Field + T & 32507 & 1117 & 13462 & 4144 & 74576 & 55 & 2180 & 52 \\
\hline pXRF Field + SOM & 32068 & 1094 & 13447 & 4218 & 90848 & 70 & 2381 & 54 \\
\hline pXRF Field $+M+T$ & 32830 & 1126 & 13296 & 4193 & 73670 & 56 & 2193 & 53 \\
\hline pXRF Field + M + SOM & 31524 & 1135 & 13360 & 4194 & 91808 & 67 & 2296 & 55 \\
\hline pXRF Field + T + SOM & 33163 & 1115 & 12943 & 4163 & 79740 & 54 & 2108 & 53 \\
\hline \multirow[t]{2}{*}{ pXRF Field + M + T + SOM } & 33151 & 1128 & 13506 & 4213 & 76333 & 56 & 2243 & 54 \\
\hline & \multicolumn{8}{|c|}{$\mathrm{RI}(\%)$} \\
\hline pXRF Field & - & - & - & - & - & - & - & - \\
\hline pXRF Field + M & 0.15 & -0.99 & 0.03 & -0.47 & 5.11 & 0.59 & 0.76 & -1.63 \\
\hline pXRF Field $+T$ & -3.20 & 1.13 & -1.52 & 1.28 & 20.29 & 17.90 & 7.80 & 3.23 \\
\hline pXRF Field + SOM & -1.80 & 3.19 & -1.40 & -0.49 & -0.59 & -0.01 & -0.68 & -0.70 \\
\hline pXRF Field $+M+T$ & 0.97 & 0.36 & -0.26 & 0.49 & 19.11 & 18.90 & 7.26 & 0.43 \\
\hline pXRF Field + M + SOM & -0.08 & -0.43 & -0.75 & 0.09 & 2.56 & -1.07 & 3.13 & -2.98 \\
\hline pXRF Field + T + SOM & -5.28 & 1.34 & 2.40 & 0.82 & 22.29 & 12.21 & 11.18 & -0.10 \\
\hline pXRF Field + M + T+SOM & -5.24 & 0.19 & -1.85 & -0.36 & 19.41 & 15.97 & 5.16 & -0.94 \\
\hline
\end{tabular}




\section{CONCLUSIONS}

The elemental/oxides contents obtained by pXRF in field soil analysis and under laboratory conditions (in ADFE) varied for all analyzed elements/oxides. However, models for prediction of the contents in ADFE could be well adjusted for conversion of the results obtained in field for most elements/oxides. In general, soil texture coupled with field pXRF analyses was more helpful to predicting the elemental content of ADFE results than moisture and soil organic matter. $\mathrm{Fe}$ and $\mathrm{K}_{2} \mathrm{O}$ contents in ADFE could be satisfactorily predicted from field data, without the addition of soil organic matter, texture or soil moisture. For $\mathrm{CaO}$ and $\mathrm{Zr}$, results were less expressive even with the addition of all the auxiliary variables to the models. Thus, through simple models, it is possible to convert the pXRF results obtained in field into those obtained in $\mathrm{ADFE}$ for $\mathrm{Al}_{2} \mathrm{O}_{3}, \mathrm{SiO}_{2}, \mathrm{Fe}$, $\mathrm{K}_{2} \mathrm{O}, \mathrm{V}$ and Ti with or without the need to include auxiliary variables (T, M or SOM) according to the element.

\section{ACKNOWLEDGEMENTS}

The authors would like to thank to the Conselho Nacional de Desenvolvimento Científico e Tecnológico (CNPq), Coordenação de Aperfeiçoamento de Pessoal de Nível Superior (CAPES), and Fundação de Amparo à Pesquisa de Minas Gerais (FAPEMIG) for scholarships and for the financial support that enabled the development of this research.

\section{REFERENCES}

AIDE, M. Geochemical assessment of iron and vanadium relationships in oxic soil environments. Soil and Sediment Contamination: An International Journal, 14(5):403-416, 2005.

ALDABAA, A. A. A. et al. Combination of proximal and remote sensing methods for rapid soil salinity quantification. Geoderma, 239-240:34-46, 2015.

ALVES, M. J. F. et al. Reserva mineral de potássio em Latossolo cultivado com Pinus taeda L. Revista Brasileira de Ciência do Solo, 37(6):1599-1610, 2013.

ARAUJO, M. A. et al. Paragênese mineral de solos desenvolvidos de diferentes litologias na região sul de Minas Gerais. Revista Brasileira de Ciência do Solo, 38(1):11-25, 2014.

BASTOS, R. O.; MELQUIADES, F. L.; BIASI, G. E. V. Correction for the effect of soil moisture on in situ XRF analysis using low-energy background. X-Ray Spectrometry, 41(5):304$307,2012$.
BERGER, M.; ZOU, L.; SCHLEICHER, R. Analysis of sulfur in the copper basin and muddy river sites using portable XRF instrumentation. International Journal of Soil, Sediment and Water, 2(3):1-17, 2009.

CENTURION, J. F.; ANDRIOLI, I. Regime hídrico de alguns solos de Jaboticabal. Revista Brasileira de Ciência do Solo, 24(4):701-709, 2000.

CURI, N. et al. Geomorfologia, física, química e mineralogia dos principais solos da região de Lavras (MG). Ciência e Prática, 14(3):297-307, 1990.

CURI, N.; FRANZMEIER, D. P. Effect of parent rocks on chemical and mineralogical properties of some Oxisols in Brazil. Soil Science Society of America Journal, 51(1):153-158, 1987.

DANTAS, A. A. A.; CARVALHO, L. G. DE; FERREIRA, E. Classificação e tendências climáticas em Lavras, MG. Ciência e Agrotecnologia, 31(6):1862-1866, 2007.

FOLEY, J. A. et al. Global Consequences of Land Use. Science, 309(5734):570-574, 2005.

GE, L.; LAI, W.; LIN, Y. Influence of and correction for moisture in rocks, soils and sediments on in situ XRF analysis. X-Ray Spectrometry, 34(1):28-34, 2005.

GEE, G. W.; BAUDER, J. W. Particle-size analysis. In: KLUTE, A. (Ed.). Methods of Soil Analysis. Part 1 - Physical and Mineralogical Methods. 2nd. ed. Madison, WI: SSSA, 1986. p.383-411.

HANGEN, E.; VIETEN, F. Influence of soil pore length upon portable X-ray fluorescence spectrometer measurements of elements in soils. Water, Air, \& Soil Pollution, 227(5):143, 2016.

HUDSON, B. D. Soil organic matter and available water capacity. Journal of Soil and Water Conservation, 49(2):189-194, 1994.

KABATA-PENDIAS, A. Trace Elements in Soils and Plants. 4th. ed. Boca Raton: CRC Press, 2010. 548p.

KÄMPF, N.; MARQUES, J. J.; CURI, N. Mineralogia de solos brasileiros. In: KER, J. C. et al. (Ed.). Pedologia: Fundamentos. 1. ed. Viçosa, MG: SBCS, 2012. p.343.

KUHN, M. et al. Package 'caret', 2018. Available in: https:// github.com/topepo/caret/. Access in: Oct. 25, 2019.

LEMIERE, B. et al. Portable XRF and wet materials: Application to dredged contaminated sediments from waterways. Geochemistry: Exploration, Environment, Analysis, 14(3):257-264, 2014. 
MANCINI, M. et al. Tracing tropical soil parent material analysis via portable X-ray fluorescence ( $p X R F)$ spectrometry in Brazilian Cerrado. Geoderma, 337:718728, 2019a.

MANCINI, M. et al. Parent material distribution mapping from tropical soils data via machine learning and portable X-ray fluorescence (pXRF) spectrometry in Brazil. Geoderma, 354:113885, 2019b.

MARQUES, J. J. et al. Major element geochemistry and geomorphic relationships in Brazilian Cerrado soils. Geoderma, 119(3-4):179-195, 2004.

MARTIN, H. W.; KAPLAN, D. I. Temporal changes in cadmium, thallium, and vanadium mobility in soil and phytoavailability under field conditions. Water, Air, and Soil Pollution, 101(1):399-410, 1998.

MONROE, J. S.; WICANDER, R. Geologia. 2nd. ed. Cengage Learning, 2017. 464p.

O'ROURKE, S. M. et al. An assessment of model averaging to improve predictive power of portable vis-NIR and XRF for the determination of agronomic soil properties. Geoderma, 279:31-44, 2016.

PARSONS, C. et al. Quantification of trace arsenic in soils by field-portable X-ray fluorescence spectrometry: Considerations for sample preparation and measurement conditions. Journal of Hazardous Materials, 262:12131222, 2013.

POTTS, P. J.; WEST, M. Portable X-ray fluorescence spectrometry: Capabilities for in vitro analysis. Cambridge: Royal Society of Chemistry, 2008. 304p.

QUÉMÉNEUR, J. J. G. et al. Mapa geológico - Folha Lavras SF 23-X-C-I. escala 1:100.000. Belo Horizonte: COMIG, 2002.

R CORE TEAM. R: A language and environment for statistical computing. Vienna, Austria. R Foundation for Statistical Computing, 2019. Available in: https://www.r-project.org/. Access in: Jan. 17, 2019.

RAVANSARI, R.; LEMKE, L. D. Portable X-ray fluorescence trace metal measurement in organic rich soils: pXRF response as a function of organic matter fraction. Geoderma, 319:175-184, 2018.

RESENDE, M. et al. Pedologia: Base para distinção de ambientes. 6a edição ed. Lavras: Editora UFLA, 2014. $378 p$.
RESENDE, M. et al. Da rocha ao solo: Enfoque ambiental. 1. ed. Lavras: Editora UFLA, 2019. 512p.

RIBEIRO, B. T. et al. Portable X-ray fluorescence (pXRF) applications in tropical Soil Science. Ciência e Agrotecnologia, 41(3):245-254, 2017.

RIBEIRO, B. T. et al. The influence of soil moisture on oxide determination in tropical soils via portable $X$-ray fluorescence. Soil Science Society of America Journal, 82(3):632-644, 2018.

SAHRAOUI, H.; HACHICHA, M. Effect of soil moisture on trace elements concentrations using portable X-ray fluorescence spectrometer. Journal of Fundamental and Applied Sciences, 9(1):468-484, 2017.

SANTANA, M. L. T. et al. Elemental concentration via portable $x$-ray fluorescence spectrometry: Assessing the impact of water content. Ciência e Agrotecnologia, 43:e029218, 2019.

SANTOS, H. G. DOS et al. Sistema Brasileiro de Classificação de Solos. 5. ed. Brasília, DF: Embrapa, 2018. 356p.

SCHNEIDER, A. R. et al. Comparison of field portable XRF and aqua regia/ICPAES soil analysis and evaluation of soil moisture influence on FPXRF results. Journal of Soils and Sediments. 16(2):438-448, 2016.

SHAND, C. A.; WENDLER, R. Portable X-ray fluorescence analysis of mineral and organic soils and the influence of organic matter. Journal of Geochemical Exploration, 143:31-42, 2014.

SHARMA, A. et al. Characterizing soils via portable X-ray fluorescence spectrometer: 3. Soil reaction $(\mathrm{pH})$. Geoderma, 232-234:141-147, 2014.

SILVA, S. H. G. et al. Multiple linear regression and random forest to predict and map soil properties using data from portable X-ray fluorescence spectrometer (pXRF). Ciência e Agrotecnologia, 41(6):648-664, 2017.

SILVA, S. H. G. et al. Tropical soils characterization at low cost and time using portable X-ray fluorescence spectrometer ( $p X R F)$ : Effects of different sample preparation methods. Ciência e Agrotecnologia, 42(1):80-92, 2018.

SILVA, S. H. G. et al. Modeling and prediction of sulfuric acid digestion analyses data from pXRF spectrometry in tropical soils. Scientia Agricola, 77(4):e20180132, 2019. 
SOIL SURVEY STAFF. Keys to soil taxonomy. 12th ed. Washington, DC: USDA-NRCS, 2014.

STOCKMANN, U. et al. Utilizing portable X-ray fluorescence spectrometry for in-field investigation of pedogenesis. Catena, 139:220-231, 2016a.

STOCKMANN, U. et al. The effect of soil moisture and texture on Fe concentration using portable X-ray fluorescence Spectrometers. In: HARTEMINK, A. E.; MINASNY, B. (Eds.). Digital Soil Morphometrics. Cham: Springer International Publishing, 2016b. p.63-71.

WALKLEY, A.; BLACK, I. A. An examination of the Degtjareff method for determining soil organic matter and a proposed modification of the chromic acid titration method. Soil Science, 37(1):29-38, 1934.
WEINDORF, D. C. et al. Lithologic discontinuity assessment in soils via portable X-ray fluorescence spectrometry and visible near-infrared diffuse reflectance spectroscopy. Soil Science Society of America Journal, 79(6):1704-1716, 2015.

WEINDORF, D. C.; BAKR, N.; ZHU, Y. Advances in portable X-ray fluorescence (PXRF) for environmental, pedological, and agronomic applications. Advances in Agronomy. 128:652113, 2014

ZHANG, J. et al. Soil physical characteristics of a degraded tropical grassland and a 'reforest': Implications for runoff generation. Geoderma, 333:163-177, 2019.

ZHU, Y.; WEINDORF, D. C.; ZHANG, W. Characterizing soils using a portable X-ray fluorescence spectrometer: 1 . Soil texture. Geoderma, 167-168:167-177, 2011. 